\title{
The Effectiveness of SIAP TARIK to Improve the Quality of Health Services
}

\author{
Lailul Mursyidah, Ilmi Usrotin Choiriyah, Mai Puji Lestari, Isnaini Rodiyah \\ Departement of Public Administration, Faculty of Bisnis, Law, and Social Sciences, \\ Universitas Muhammadiyah Sidoarjo (email: lailulmursyidah@umsida.ac.id)
}

\begin{abstract}
SIAP TARIK (Sistem Informasi Antrian Puskesmas Tarik) is a public service innovation in health service. SIAP TARIK is the application for ordering the queue number at the Puskesmas (health center) Tarik, Sidoarjo. This research aims to know the effectiveness of SIAP TARIK to improve the quality of helath service. This quantitative descriptive research is located at Puskesmas Tarik, Sidoarjo. The respondents of this reseach were patients who visited Puskesmas Tarik using incidental sampling techniques. The data is collected through questionnaire. The data analysis techniques use descriptive analysis techniques. The result of this research show that SIAP TARIK is effective to improve the quality of health service with score 4234 . The position is in the quartile interval $>3300$ up to 4290 which is categorized as effective. These result are indicated by the score of sistem quality, information quality, service quality, utilization, satisfaction of use, and net benefits are in effective position.
\end{abstract}

\section{Keywords:}

effectiveness; public service innovation; health services

\section{Introduction}

Public service quality is the right of every citizen that must be met in the era of globalization with the development of technology. Public service quality can be realized through public service innovation. The realization of public service quality is done to achieve World Class Government in 2025. Public service quality can be achieved by following the development of the society needs of an increasingly advanced (Laily \& Eva, 2017). The development of information technology has made conventional service systems shift to electronic-based service systems in accordance with Presidential Instruction No. 3 of 2003 concerning E-Government Development Policies and Strategies. The issuance of these instructions is evidence of the government seriousness to improve the quality of services through electronic government. 
Kase explained that electronic government (e-government) refers to the use of information technology by government organizations so that the organization becomes more effective and transparent. E-government is expected to improve the quality of services to the community, the internal effectiveness of government organizations and the people's access to information in the government environment more easily (Nugraha, 2018).

Law Number 25 of 2009 concerning Public Services explains that the public has the right to get quality services in accordance with the principles and objectives of the service. Public service innovations carried out by government agencies as a form of meeting the needs of services for the community. The service need is to provide an innovative public service that must help and facilitate direct services to the community. Public service innovation is a way to develop effectiveness in improving the public service quality. One way to be able to develop a level of effectiveness is to increase creativity and innovation in government, starting from the individual level, increasing to groups, and then heading to organizational innovation. Health services are closely related to community welfare and are absolute. Therefore, the state and its apparatus are obliged to provide quality services that are easily obtainable at any time by the public. One manifestation of the provision of public services in the health sector is Puskesmas (health center). Puskesmas aims to provide quality, satisfying and comfortable services. Puskesmas Tarik as one of the public services has the latest breakthrough innovations in overcoming queue problems. Queue problems cause Puskesmas narrow waiting rooms to become full, thus allowing the high level of saturation of service users. These conditions cause the quality of Puskesmas Tarik services to be low.

Quality of service is a determining factor in the success of government administration. Quality of service is a desire and need that must be created by the apparatus for the community (Tjiptono, 2005). The causes of the low quality of the service queues of conventional registration counters at the Puskesmas Tarik include (1) No receptionist services, (2) There is no optimal medical records, (3) Take the queue number must come to the Puskesmas (health center), (4) How to search medical records is still manual for patients who do not carry medical treatment cards, (5) The time required by officers in searching the patient's medical record folder is quite long, (6) There is no good queue system application, (7) The registration system still distinguishes new and old patients, (8) Medical record arrangement that is not in accordance with the standard, (9) Medical records folder still uses 
family folders, (10) Medical records folder still uses paper folders that are easily damaged and torn, (11) The unavailability of an adequate internet network at the Puskesmas), (12) The counter space is too crowded, (13) The number of patient visits is increasing every day, (14) Patients often forget to bring a treatment card, (15) Patients complain if they wait too long (Puskesmas Tarik, 2017) .

Puskesmas Tarik makes alternative solutions through e-government based public service innovation under the name SIAP TARIK (Sistem Informasi Antrian Puskesmas Tarik). SIAP TARIK innovation is oriented to improving services to the community effectively and efficiently. The improvements made by the Puskesmas refer to the current conditions of the Tarik community where most Puskesmas visitors have used Smart Phones. SIAP TARIK application innovation is a form of public service innovation that aims to simplify and accelerate the service queue of patients through the android application system or short messages service. Since the application of the SIAP TARIK application began in April 2017, the number of patients taking conventional queues has decreased. SIAP TARIK system informs patients about their queue number. With this application, the service room does not cause queue density and makes patients comfortable because the community can wait in line from their respective homes.

The description of the application SIAP TARIK is an application for ordering queue numbers that exist at the Puskesmas Tarik Sidoarjo. The application features can be downloaded via Google Play or Apple Store. This application provides information about diseases, doctor profiles, and other features. The realization of SIAP TARIK application that are achievement for visitors who have their health checked can be served without having to wait too long to get health services.

The SIAP TARIK application is a way to facilitate employees in providing services to the community. The achievement of the objectives of SIAP TARIK application shows the effectiveness of these innovations to solve service problems in Puskesmas Tarik. Puskesmas are expected to have a service quality value, which are efficient, innovative and produce according to Regulation of Health Minister Number 75 of 2014 concerning Puskesmas. Through the SIAP TARIK application, patients can take the queue number from home and monitor the extent of the queue taking place at the Puskesmas. That is because SIAP TARIK application uses a real time queue system. In addition to breaking down the density of the 
queue, improvements were made to the quality aspect of the medical record from the family folder (one family incorporated in one simple folder) to become a personal folder (one person, having a special folder that contains the patient's medical history during treatment at the Puskesmas). The medical search system has also changed, from manual search to integrated with information technology so that searching for medical record numbers of patients who do not carry medical cards can be done faster. Therefore, it is necessary to do an assessment of the benefits or usefulness of the SIAP TARIK information system program to measure its effectiveness. Based on these descriptions the authors are interested in aiming to know the effectiveness of SIAP TARIK to improve the quality of health services.

\section{Methods}

This quantitative descriptive research is located at Puskesmas (health center) Tarik, Sidoarjo. The variable in this study is the effectiveness of SIAP TARIK (Sistem Informasi Antrian Puskesmas Tarik). The effectiveness variable refers to the assessment of 5 indicators of information system effectiveness variables according to DeLone and McLean (2003) which include system quality, information quality, service quality, use, user satisfaction, net benefit. Variables are presented in a questionnaire with instruments that use a Likert scale measuring instrument with 4 measurement scales as alternative answers, which are very effective, effective, not yet effective, and very ineffective.

The respondents were patients who visited the Puskesmas withdraw using incidental sampling techniques. There are 60 respondents of this research. The data has been collected through questionnaire. The data validity technique has been done through validity and reliability testing. The conclusion of the effectiveness level (Azwar, 1988) has been done by looking at the position of the results calculation of perception score in the quartile that exists between the lower boundary (B) and the upper boundary score (A). Measurement of effectiveness using the score of the lower limit (B) and the upper limit (A) is calculated by the formula:

$B=$ Number of respondents $x$ lowest score $x$ number of questions

$A=$ Number of respondents $x$ highest score $x$ number of questions

After determining the lower limit (B) and the upper limit (A), the quartile value between $\mathrm{B}$ and $\mathrm{A}$ is then determined by the following calculation: 
Quartile I (Q1) = B + n/4

Quartile II $(\mathrm{Q} 2)=\mathrm{B}+\mathrm{n} / 2$

Quartile III $(\mathrm{Q} 3)=\mathrm{B}+\mathrm{n}^{3} / 4$

Explanation: $\mathrm{n}=$ range between $\mathrm{B}$ and $\mathrm{A}$

where the value of $\mathrm{n}$ is determined in order

$\mathrm{n}=$ score of $\mathrm{A}-$ score of $\mathrm{B}$

The data analysis techniques use descriptive analysis techniques. Descriptive is obtained by entering the number of respondents' characteristics of each indicator in the effectiveness level table.

Tabel 1.

Measurement of Effectiveness

\begin{tabular}{ll}
\hline Total Score Positions & Level of Effectiveness \\
\hline B to $Q 1$ & Very not effective \\
\hline$>$ Q1 to $Q 2$ & Not effective \\
\hline$>$ Q2 to Q3 & Effective \\
\hline$>$ Q3 & Very effective \\
\hline
\end{tabular}

\section{Results and Discussion}

The research data was collected from January 7, 2019 to January 21, 2019. Primary data in this study were obtained through research instruments in the form of questionnaire statement items. The questionnaire distributed contained 22 statements that had been tested for validity and reliability. Each item in the questionnaire has four alternative answers provided. Based on the characteristics of the respondents, each variable statement was calculated using the SPSS 20 for windows program in order to obtain statistical data about the effectiveness of the SIAP TARIK (Sistem Informasi Antrian Puskesmas Tarik) and the measurement of its effectiveness level. The conclusion of effectiveness is measured by calculating each variable by looking at the position of questionnaire calculations number.

1. System Quality

Based on calculations using the SPSS 20 for windows program, it is obtained that the position number of the effectiveness of system quality variable is 763 . The score is categorized as effective, which means it is located in intervals $>600$ to 780 . Therefore, it can be seen that the system quality of SIAP TARIK is good and effective. Most respondents think that SIAP TARIK service is easy to use, including the queuing number 
collection service that can be accessed online through SIAP TARIK application, reliable, fast access and in line with the queue sequence number.

2. Information Quality

Based on calculations using the SPSS 20 for windows program, the result of the position number of the effectiveness of information quality variable is 971 . The score is categorized as effective, which means it is located in intervals $>750$ to 975 . Therefore, it can be seen that information quality of SIAP TARIK service it's good and effective. Most of the respondents consider that the use of SIAP TARIK service is easy to understand, providing complete information. Likewise with health services that provide the latest information, accurate and can be accounted for, and maintained consistency.

3. Service Quality

Based on calculations using the SPSS 20 for windows program, the result of the position number of the effectiveness of service quality variable is 768 . The score is categorized as effective, which means it is located in intervals $>600$ to 780 . Therefore, it can be seen that the service quality of SIAP TARIK services it's good and effective. Most of the respondents consider that SIAP TARIK services is equipped with sophisticated hardware and equipment, service personnel are able to serve with good communication, fast response staff and in accordance with service standards.

4. Use

Based on calculations using the SPSS 20 for windows program, the result of the position number of the effectiveness of use variable is 384 . The score is categorized as effective, which means it is located in intervals $>300$ to 390 . Therefore, it can be seen that the use of SIAP TARIK service is good and effective. Most respondents always use SIAP TARIK application in health services because the application access is fast. In addition, respondents prefer taking online queue numbers using SIAP TARIK service.

5. User Satisfaction

Based on calculations using the SPSS 20 for windows program, the result shows that the number of the effectiveness of user satisfaction is 374 . The score is categorized as effective, which means it is located in intervals $>300$ to 390 . Therefore, it can be seen that the user satisfaction of SIAP TARIK service it's good and effective. Most respondents were 
satisfied with this service and would use it again. In addition, the respondent considers that SIAP TARIK provides actual information.

6. Net Benefits

Based on calculations using the SPSS 20 for windows program, the result of the position number of the effectiveness of information quality variable is 974 . The score is categorized as effective, which means it is located in intervals $>7500$ to 974 . Therefore, it can be seen that the net benefits of SIAP TARIK services it's good and effective. Most respondents agreed that SIAP TARIK services can reduce the density of registration window space, the service is fast, can be used as an example and guide for always being productive in making breakthroughs or new innovations to improve the service quality of Puskesmas Tarik.

Overall, the results of the calculation of SIAP TARIK effectiveness from all variables using the SPSS 20 program for windows obtained the position of the total effectiveness is 4234 . The score is categorized as effective, which means it is located in intervals $>3300$ to 4290 . Most respondents choose to use SIAP TARIK because queue numbers can be ordered online through the application. In addition, information about health is complete and accurate, access is fast and responsive, not slow so that many respondents are satisfied with this service.

\section{Conclusion}

Based on the results of the study it can be seen that the Puskesmas Tarik Queue Information System (SIAP TARIK) is in the effective category. These results are supported by the results of the calculation of the effectiveness level of six information system variables which are also in the effective category. The six variables of information system effectiveness include system quality, information quality, service quality, use, user satisfaction, and net benefits. The level of SIAP TARIK effectiveness shows that SIAP TARIK innovation is effective in improving the quality of health services.

\section{References}

Azwar, S. (1988). Sikap Manusia Teori dan Pengukurannya. Yogyakarta: Liberty. Indrajit, E. R. (2002). Electronic Government. Yogyakarta: Andi Offset. 
Laily, T. F., \& Eva, H. F. (2017). Efektivitas Sistem Informasi Layanan Sidoarjo Maternal Neonatal Emergency SMS Gateway (SIMANEIS) Di Rumah Sakit Umum Daerah Sidoarjo. Publika, Volume 05 Nomor (2), Hal 1-8.

Menteri Kesehatan Republik Indonesia. (2014). Peraturan Menteri Kesehatan Republik Indonesia Nomor 75 Tahun 2014 tentang Puskesmas. Retrieved from http://www.depkes.go.id/resources/download/peraturan/PMK-No-75-Th-2014-ttgPuskesmas.pdf

Nugraha, T. J. (2018, April). E-Government dan Pelayanan Publik (Studi Tentang Elemen Sukses Pengembangan E-Government di Pemerintah Kabupaten Sleman). Jurnal Komunikasi dan Kajian Media, Volume 2 Nomor (1), Hal 32-42.

Presiden Republik Indonesia. (2003). Instruksi Presiden No. 3 Tahun 2003 tentang Kebijakan dan Strategi Pengembangan E-Government. Retrieved from https://eppid.kominfo.go.id/uploads/instruksi_presiden_no_3_th_200311.pdf.

Presiden Republik Indonesia. (2009). Undang - Undang Republik Indonesia Nomor 25 Tahun 2009 tentang Pelayanan Publik. Retrieved from https://pelayanan.jakarta.go.id/download/regulasi/undang-undang-nomor-25tahun-2009-tentang-pelayanan-publik.pdf Tjiptono, F. (2005). Prinsip-Prinsip Total Quality Service. Yogyakarta: Penerbit ANDI. Tjiptono, F., \& Chandra, G. (2005). Service, Quality \& Satisfaction. Yogyakarta: Andi Offset. 